ties of fruits on the ground directly under the canopy after thinning. Fruits removed from each tree at thinning were counted in 1988. Thinning intensity for 1988 was determined by dividing the number of fruit removed at thinning by trunk cross-sectional area $30 \mathrm{~cm}$ above the bud union. Fruit were harvested from 24 July through 5 Aug. 1987 and 'from 29 July through 9 Aug. 1988. Production efficiency was estimated by dividing yield per tree by the trunk cross-sectional area 30 $\mathrm{cm}$ above the bud union. Tree vigor was estimated by calculating the increase in trunk cross-sectional area each growing season before the freeze. For data consisting of multiple observations per tree, mean values of the response variable per tree were calculated arid used in the analysis. All data were analyzed using analysis of variance and rootstock means were separated with the RyanEinot-Gabriel-Welsch multiple F test (SAS Institute, Inc., 1985), a conservative mean separation technique that controls the experiment-wise error rate.

Flower bud survival was significantly affected by rootstock in both years (Table 1). In 1987, flower buds were hardier on ' $\mathrm{Si}$ berian C' than on 'Bailey', GF 655.2, GF 677, 'Lovell', 'Halford', or 'Damas'. All stocks, except 'Bailey', imparted greater flower bud hardiness than GF 655.2. In 1988, bud hardiness was greater on 'Siberian C' and 'Bailey' than on GF 677.

The number of live pistils per $30 \mathrm{~cm}$ of terminal shoot, was also influenced by rootstock in both years. In 1987, fewer live pistils were observed on GF 677 than on 'Siberian C', 'Lovell', 'Damas', or self-rooted trees. In 1988, more live pistils were observed on 'Lovell' and 'Siberian C' than on 'Damas'. In both years, flower bud survival after the late-winter stress was not correlated with live pistils at bloom $(r=0.58, P=$ 0.13 for 1987 and $r=0.20, P=0.64$ for 1988 ). Additional bud injury must have occurred after sampling.

Fruit thinning in peach is an intensive, expensive operation. Any significant increase in bud hardiness due to rootstock might be offset by increased costs for fruit thinning. No significant rootstock effect on fruit thinning intensity was detected in 1987. All trees required light to moderate thinning. A significant rootstock effect was detected in 1988 . 'Siberian C' and 'Lovell' required the greatest fruit thinning. Thinning intensity was correlated $(r=0.84, P=0.009)$ with the number of live pistils per $30-\mathrm{cm}$ shoot, but not with flower bud survival after the latewinter stress $(r=0.42, P=0.30)$.

Marketable yield was not affected by rootstock in 1987, but was in 1988, when GF 677 produced a larger crop than GF 655.2 or 'Damas'. 'Bailey ', 'Lovell', and self-rooted trees produced a significantly larger crop than 'Damas'. Marketable yield in 1988 was two to three times higher than yield in 1987 on all rootstock. No significant rootstock effect on production efficiency was detected in either year.

Clearly, rootstock influences tree vigor (Table 1); however, no clear relationship could be discerned between flower bud hardiness and scion vigor the preceding summer.

Both flower bud survival and production efficiency were much lower than reported by Brown and Cummins (1988) for the same scion-rootstock combinations. This difference reflects the tremendous influence local environment has on rootstock performance.

In 1987, rootstock affected flower bud survival after a severe freeze, but not marketable yield. Similar results were observed in 1988. In 1988, the scion with the poorest flower bud survival, 'Redhaven' on GF 677, produced the highest yield. Thus, up to an $89 \%$ flower bud loss following a test winter may not give an adequate indication of potential yield the following growing season.

In a previous test (Durner and Rooney, 1988), rootstock did not significantly affect flower bud cold hardiness in 'Rio Oso Gem' or 'Loring' during the same 2-year test period. It appears that rootstock effects on flower bud hardiness under our climatic conditions have a minimal effect on production unless bud loss is virtually complete.

\section{Literature Cited}

Brown, S.K. and J.N. Cummins. 1988. Rootstock influenced peach flower bud survival after a natural freeze. HortScience 23:846-847.

Durner, E.F. and F.X. Rooney. 1988. 'Rio Oso Gem' and 'Loring' peach flower bud and wood hardiness as affected by different rootstocks. Fruit Var. J. 42:134-138

Layne, R.E.C. 1987. Peach rootstock, p. 185216. In: R.C. Rom and R.F. Carlson (eds.). Rootstock for fruit crops. Wiley, New York.

Layne, R. E. C., H.O. Jackson, and F.D. Stroud. 1977. Influence of peach seedling rootstock on defoliation and cold hardiness of peach cultivars. J. Amer. Soc. Hort. Sci. 102:89-92.

Ormrod, D.P. and R.E.C. Layne. 1977. Scion and rootstock influence on winter survival of peach trees. Fruit Var. J. 31:30-33.

SAS Institute, Inc. 1985. SAS/STAT guide for personal computers. version 6 ed. SAS Institute Inc., Cary, N.C.

Warrnund, M.R. and J.V. Slater. 1988. Hardiness of apple and peach trees in the NC-140 rootstock trials. Fruit Var. J. 42:20-24.

HORTSCIENCE 25(2):173-176. 1990.

\title{
Holding Tomato Transplants in Plug Trays
}

\author{
Charles W. Marr ${ }^{1}$ and Mark Jirak ${ }^{2}$ \\ Department of Horticulture, Kansas State University, Manhattan, KS \\ 66506
}

Additional index words. Lycopersicon esculentum, containers, seedling growth, fruit yield

Abstract. Tomatoes (Lycopersicon esculentum Mill. cv. Jet Star) seedlings grown in small cells (plugs) in trays holding 200,406 , or 648 plants per flat $(28 \times 55 \mathrm{~cm})$ were larger after 6 weeks as cell size increased, but all were acceptable. Other seedlings, transplanted at weekly intervals from plug trays to plastic cell packs (48 cells per 28 $\times 55-\mathrm{cm}$ flat), were of similar size during weeks 1-3; seedlings from 648-plug trays were smaller than the others by week 5-6. Seedlings from 200-plug trays planted at weekly intervals into containers where plant-plant competition was absent were larger through 6 weeks than those from 406- and 648-plug trays. Early marketable and total yields were similar for plants held in 406-plug trays 1 to 4 weeks before their transfer to 48 -cell flats, but yield decreased for those held 5 to 7 weeks.

Producing bedding plants in plug trays offers advantages of mechanization of planting and ease of transplanting to larger growing

Received for publication 16 Feb. 1988. Contribution no. 88-349-J of the Kansas Agr. Expt. Sta. Mention of trademark, proprietary product, or vendor does not constitute a guarantee or warranty and does not imply its approval to the exclusion of other products or vendors that also maybe suitable The cost of publishing this paper was defrayed in part by the payment of page charges. Under postal regulations, this paper therefore must be hereby marked advertisement solely to indicate this fact.

${ }^{1}$ Professor.

${ }^{2}$ Former horticulture student. Present address: CIBA-Geigy Co., 1502 Cardiff Terrace, Westchester, PA 19380. containers. Increasing plants per unit area of greenhouse space during initial growth conserves space and lowers production costs. Plug seedlings, plants grown in small-volume cells, are used in the production of floricultural and vegetable crops (Koransky and Laffe, 1983). In the Great Plains of the United States, where variable spring freezes make scheduling of transplanting difficult, plug trays may be used to hold seedlings before transplanting them to larger containers or into the field. Cost efficiency of greenhouse bench space would increase because of the high plant density in plug trays. Tomatoes rapidly initiate roots following transplanting (Loomis, 1924). Other researchers have obtained equal or greater yields with young or small tomato transplants (Chipman, 1961; Cooper and 

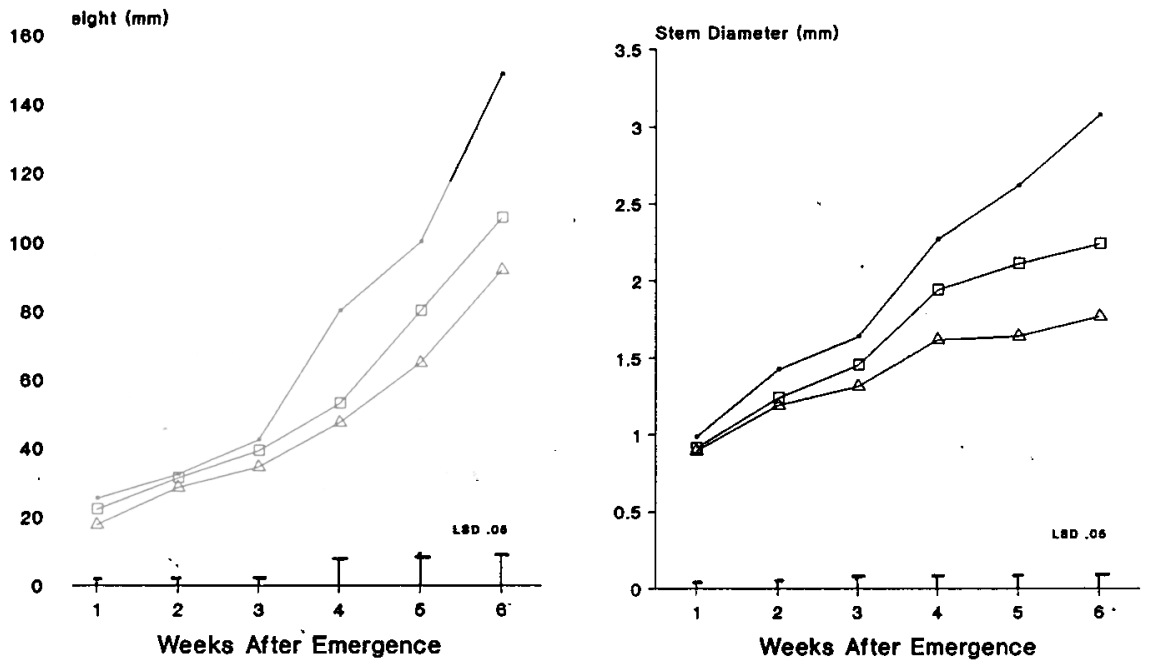

200

Dry Weight (mo/plant)

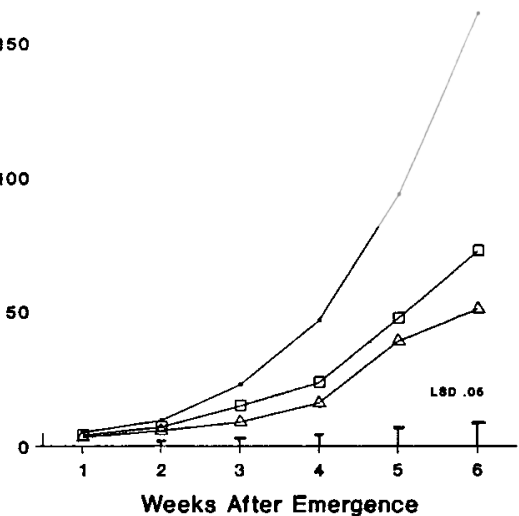

Fig. 1. Plant height (A), stem diameter (B), and dry weight (C) of tomato plants measured 1 to 6 weeks after seedling emergence in $200-(\rightarrow-)$, 406$(\square)$, and $648-(\triangle)$ plug trays.

A

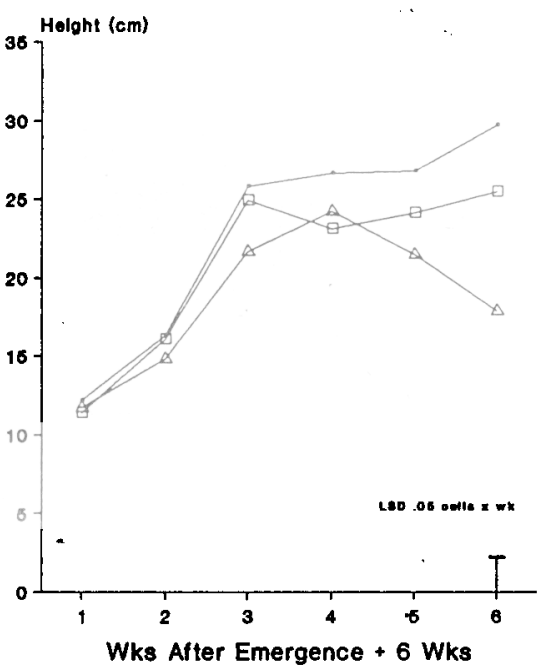

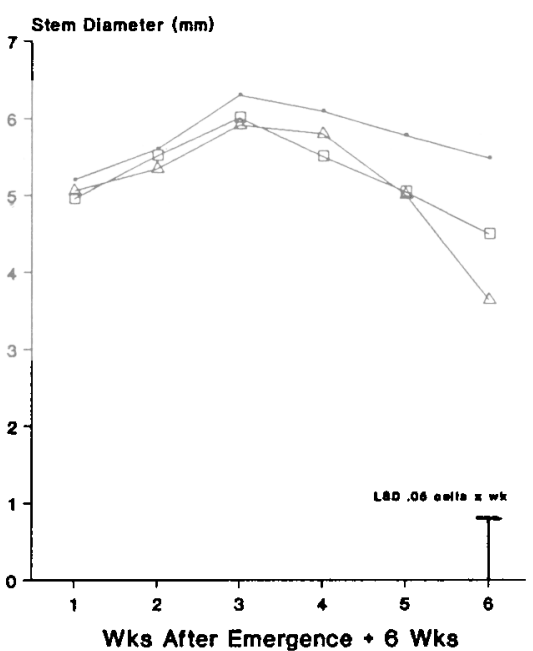

C

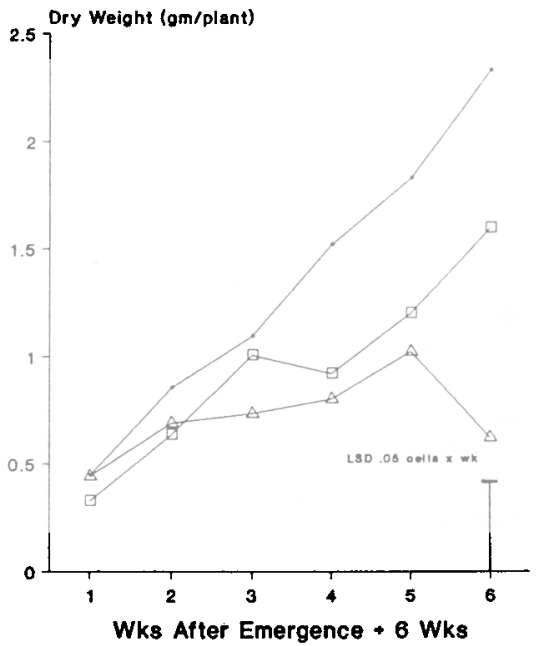

Fig. 2. Plant height (A), stem diameter (B), and dry weight (C) of tomato transplants grown for 1 to 6 weeks (after emergence) in 200- $(-\bullet-)$, 406- ( $\square$ ), and 648- $(\triangle)$ plug trays and then grown an additional 6 weeks in 48-cell market packs. Data taken after 6 weeks in 48 -cell market packs.

Morelock, 1983; Nicklow and Minges, 1962). Early yields, however, may be reduced when using small transplants (Cooper and Morelock, 1983; Sayre, 1948; Weston and Zandstra, 1986; Knavel, 1965). Ruff et al. (1987) have indicated that root volume restrictions reduced growth and altered root morphology of container-grown tomato plants. The objectives of this study were to determine 1) tomato seedling growth in three plug tray sizes, 2) transplant growth after holding seedlings in plug trays for various lengths of time, and 3) field performance of tomato seedlings held in plug trays then transplanted to containers before field-setting.

'Jet Star' tomato seeds were planted in plug trays filled with vermiculite. Trays were $28 \times 55 \mathrm{~cm}$ and held 200,406, or 648 plants per tray (Blackmore Transplanter Co., Ypsilanti, Mich.) with cell volumes of 9,3 , and $1.3 \mathrm{~cm}^{3}$, respectively. A water soluble fertilizer $(20 \mathrm{~N}-8.6 \mathrm{P}-16.6 \mathrm{~K})$ providing $150 \mathrm{ppm}$
$\mathrm{N}$ was injected at each watering. Greenhouse temperature was maintained at $22 \mathrm{C}$. Water was misted for $5 \mathrm{sec}$ every 6 to $12 \mathrm{~min}$ during daylight hours. At weekly intervals after seedling emergence, 10 seedlings chosen at random from various areas of the tray were removed, and height (medium surface to growing point), stem diameter $(1 \mathrm{~cm}$ above medium level), and dry weight were measured. Leaf area was measured using a LICOR leaf area meter (LI-COR, Lincoln, Neb.). A randomized complete-block (RCB) experimental design with four replications was used and data were analyzed by analysis of variance.

In a subsequent study, seedlings were grown as above and transplanted at weekly intervals after emergence into plastic cell packs (48 cells per $28 \times 55-\mathrm{cm}$ flat) filled with a medium of 1 loam soil : 2 peat : 2 perlite (by volume). The seedlings were grown in a $22 / 16 \mathrm{C}$ (day/night) greenhouse, and fer- tilized as above. Volume of each cell was $100 \mathrm{~cm}^{3}$. Plants of each weekly transplanting interval were grown an additional 6 weeks, and the same characteristics mentioned above were measured. A RCB design with four replications was used with 12 plants per experimental unit. Concurrently, seedlings were transplanted into large tubs $\left(0.056 \mathrm{~m}^{3}\right)$ with three plants per tub, also using RCB design with four replications. Fertilization and growing media described above were used. In a final study, seedlings were grown in 406-plug trays and transplanted at weekly intervals following emergence into plastic cell packs described above. After 7 weeks, all plants were transplanted to the field so that treatments consisted of plants of the same physiological age but differing in the amount of time they were held in the plug tray and cell packs. Transplants were set out in very fine sandy loam soil (Mollic Udifluvent coarse-silty, mixed calcareous messic) on 3 
A

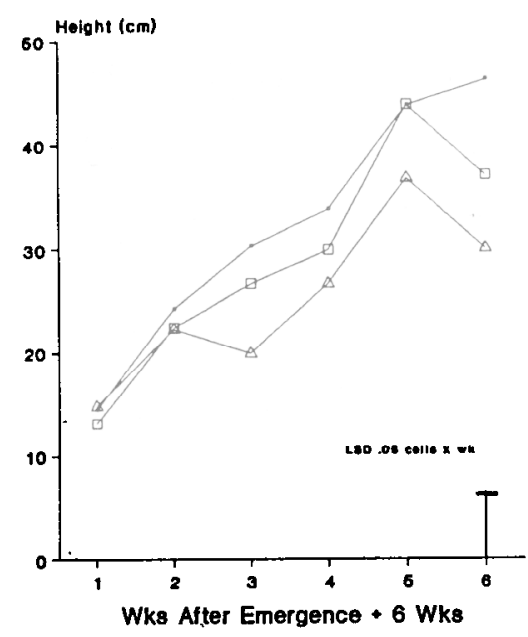

D

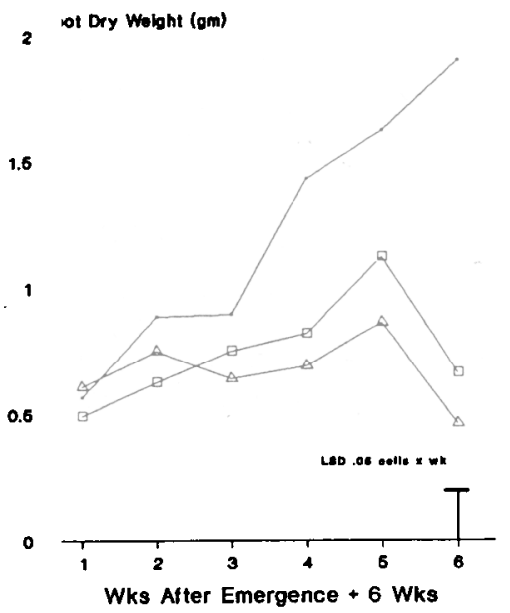

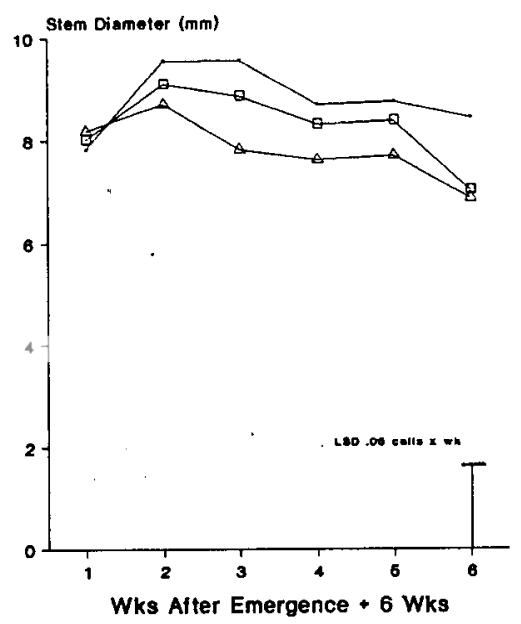

$E$

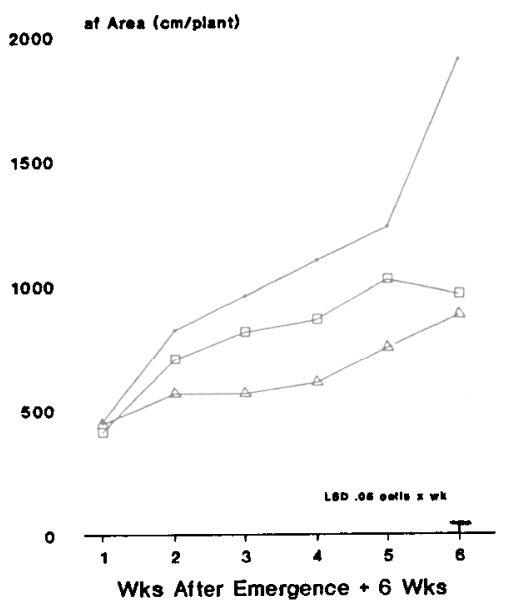

C

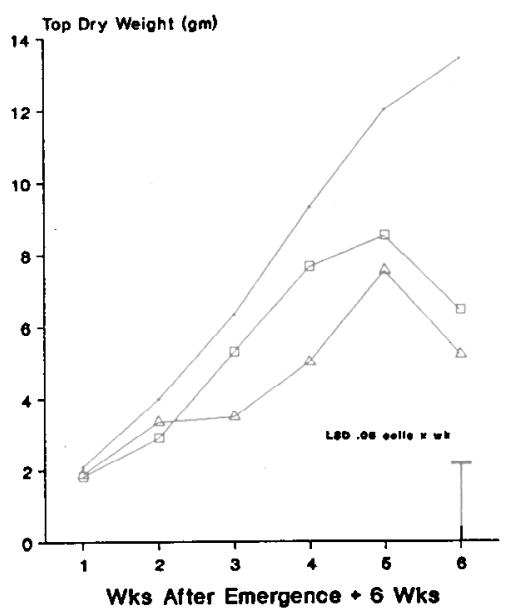

Fig. 3. Plant height (A), stem diameter (B), top dry weight (C), root dry weight (D), and leaf area (E) of tomato transplants grown for 1 to 6 weeks (after - emergence) in 200- $(\rightarrow-, 406-(\square)$, and 648- $(\triangle)$ plug trays and then grown an additional 6 weeks in large tubs. Data taken after 6 weeks in tubs.

May 1985 in a RCB design with six replications of six plants per experimental unit. Plots were fertilized with $\left(\mathrm{kg} \cdot \mathrm{ha} \mathrm{a}^{-1}\right) 40 \mathrm{~N}$ and $44 \mathrm{P}$ before planting and sidedressed with an equivalent $\mathrm{N}$ application at early fruit set. Conventional production practices were used, with plants spaced $0.6 \mathrm{~m}$ in I. S-m rows and wire cage vine supports $(0.4 \times 0.7 \mathrm{~m})$. Harvest from 16 July to 20 Aug. was recorded

Table 1. Transplant size and eventual yield of 'Jet Star' tomatoes held for various periods following emergence in 406-plug trays and 48-cell market packs before being planted in the field.

Yield $\left(\mathrm{t} \cdot \mathrm{ha}^{-1}\right)$

\begin{tabular}{crrrrrrr}
2 & -5 & 29.5 & 7.1 & 2.16 & 11.6 & 25.1 & 199 \\
3 & 4 & 35.3 & 7.4 & 1.51 & 11.6 & 23.8 & 222 \\
4 & 3 & 18.5 & 5.7 & 1.05 & 12.7 & 25.1 & 212 \\
5 & 2 & 9.4 & 4.6 & 0.26 & 9.0 & 23.6 & 204 \\
6 & 1 & 7.4 & 3.4 & 0.15 & 6.2 & 19.5 & 203 \\
7 & 0 & 5.3 & 2.4 & 0.06 & 1.3 & 17.8 & 221 \\
\multicolumn{1}{l}{ Significance } & & $\mathrm{L}^{* *} \mathrm{Q}^{* *}$ & $\mathrm{~L}^{* *} \mathrm{Q}^{* *}$ & $\mathrm{~L}^{* *} \mathrm{Q}^{* *}$ & $\mathrm{~L}^{* *} \mathrm{Q}^{* *}$ & $\mathrm{~L}^{* *}$ & $\mathrm{NS}$ \\
\hline
\end{tabular}

${ }^{2}$ Duration in container following seedling emergence.

**, ${ }^{\text {Ns }}$ Significant at $P=0.01$ or nonsignificant at $P>0.005$.

as marketable (U.S. No. 1 grade) and total yields, with the July harvest designated as early yield.

Plug seedling growth increased over time in relation to container size (Fig. 1). Although seedling size -was different at the end of week 6 for the three plug trays, all plants appeared to be in good condition and similar in color. Thus, acceptable plants could be

Yield $\left(\mathrm{t} \cdot \mathrm{ha}^{-1}\right)$

HortScience, Vol. 25(2), February 1990 held 6 weeks in any size tray. In the study in which plants were moved at weekly intervals to the larger 48-cell packs and grown for an additional 6 weeks, plants from the 648-plug trays were shorter and had smaller stem diameters than the others after week 4 (Fig. 2). Dry weight of these plants had declined by week 6 . Height of plants from 406plug trays did not increase during weeks 36 , whereas those from 200-plug trays continued to grow. In the large tubs (Fig. 3), a similar pattern of growth was observed as in the 48-cell packs. Plants from both 406- and 648-plug trays were smaller, except for leaf area, than those from 200-plug trays by week 6 . Root weight increase was similar in plants during weeks 3-6. Ruff et al. (1987) have reported that root restrictions limit growth and alter root morphology of tomatoes. Although the seedling plants continued to grow when held in plug trays for the 6 weeks of this study, the plants did not resume growth at the same rate when moved to market packs or to the large tub containers, possibly due to a root restriction in the small cells.

Transplant size increased with growth time in market packs when plants from 406-plug trays were held for various times in the trays 
or 48-cell market packs before being transplanted to the field 7 weeks after emergence. Early marketable and total yield were similar for plants held in plug trays for 1 to 4 weeks, despite the considerable differences in transplant size (Table 1). In comparing 5- and 7week tomato transplants, Cooper and Morelock (1983) noted that 5-week-old plants had greater total yields, whereas 7-week-old plants yielded earlier. Liptay et al. (1981) indicated that plants with small stem diameters produced lower early and total yields. Weston and Zandstra (1986) used small transplants that were comparable in size to the 6- and 7-week plug plants used in this study, with similar reductions in early yield. Also, they reported that early yields increased with largersize plants.

The results of this study indicate that plants of the same physiological age, but varying considerably in size at transplanting, produce similar early yields. Therefore, seedling plants may be held in plug trays for up to 4 weeks followed by 3 weeks of growth in a larger container and thereby reduce space that would be required for a full 6 weeks in the larger containers. Although no field studies were done to confirm production potential of plants held in plug trays, it appears that plants may be held for up to 6 weeks. By 6 weeks, however, some reduction in regrowth potential was observed in plants from the 406- and 648-plug trays. Field studies under differing environments are needed to explore applications of plug transplant production for tomatoes.

\section{Literature Cited}

Chipman, E. 1961. The effect of time of seeding and plant topping on the production of early and total yields of ripe tomatoes. Proc. Amer. Soc. Hort: Sci. 77:483-486.

Cooper, P. and T. Morelock. 1983. Effect of transplant age on earliness, total yield, and fruit weight of tomato. Arkansas Farm Res. 32(5):6.

Koransky, D. and S. Laffe. 1983. Plug production. Iowa State Univ. Mimeo., Ames.

Knavel, D.E. 1965. Influence of container size, and spacing on growth of transplants and yield of tomato. Proc. Amer. Soc. Hort. Sci. 86:582586.

Liptay, A., C. Jaworski, and S. Phatak. 1981. Effect of tomato transplant stem diameter and ethylene treatment on tomato yield. Can. J. Plant Sci. 61(2):413-415.

Loomis, W. 1924. Studies on the transplanting of vegetable crops. Cornell Agr. Expt. Sta. Memo. 87.

Nicklow, C. and P. Minges. 1962. Plant growing factors influencing the performance of 'Fireball' tomato. Proc. Amer. Soc. Hort. Sci. $81: 443-450$

Ruff, M., D. Krizek, R. Mirecki, and D. Inouye. 1987. Restricted root zone volume: Influence on growth and development of tomato. J. Amer. Soc. Hort. Sci. 112(5):763-769.

Sayre, C. 1948. Early and total yields of tomatoes as affected by time of seeding, topping the plants, and space in the flats. Proc. Amer. Soc. Hort. Sci. 51:367-370.

Weston, L. and B. Zandstra. 1986. Effect of root container size and location of production on growth and yield of tomato transplants. J. Amer. Soc. Hort. Sci. 11(4):498-501.

HortSCIENCE 25(2):176-178. 1990.

\title{
Tree and Fruit Growth of 'Napoleon' Cherry in Response to Rootstock and Planting Method
}

\author{
Anita N. Miller ${ }^{1}$, Porter B. Lombard ${ }^{2}$, Melvin N. Westwood ${ }^{3}$, and \\ Robert L. Stebbins ${ }^{4}$ \\ Department of Horticulture, Oregon State University, Corvallis, \\ OR 97331
}

Additional index words. Prunus avium, Colt, F/12-1, MxM60, tree planting, yield efficiency

Abstract. 'Napoleon' grafted onto Colt, F/12-1, and MxM60 rootstock were planted into three types of tree holes: augered; backhoed, and backhoed plus fumigation. The auger treatment resulted in lower yields, smaller trunk cross-sectional area (TSCA), and smaller canopy volume when compared to backhoed holes. Fumigation had no significant effect. Trees on Colt rootstock were more precocious, had a smaller TCSA and canopy volume, greater cumulative yield efficiency, and, in 1987, the smallest fruit weight. The yield efficiency of Colt was the highest until 1988, when it was surpassed by MxM60, but was still similar to F/12-l. Yields were highest on trees of MxM60 in 1987 and 1988.

Sweet cherries in western Oregon are sometimes grafted onto the Prunus avium L. clone F/12-l. This rootstock has good resistance to bacterial canker disease caused by Pseudomonas syringae pv. syringae Van Hall. Highly susceptible to bacterial canker, yet horticulturally desirable, genotypes such as 'Napoleon' are high-budded or grafted onto limbs of F/12-1 to decrease tree losses (Cameron, 1971). However, F/12-1 produces vigorous trees that are often slow to begin bearing (Stebbins et al., 1978).

Clones of hybrids between mahaleb (Prunus mahaleb) and mazzard (P. avium) were selected by L. Brooks, an Oregon nurseryman. Growth control and canker resistance on several of these rootstock have been reported (Stebbins et al., 1978; Westwood, 1978; Stebbins and Cameron, 1984; Perry, 1987). However, because of undesirable characteristics, such as excessive suckering (MxM2), weak understock (MxM97), drooping growth habit (MxM39), and excessive dwarfing (MxM14), only MxM60 remains as a promising rootstock. Previous research by Stebbins and Cameron (1984) determined that trees on this rootstock suckered more than F/12-1, but were only twothirds as large. MxM60 is also resistant to Phytophthora cambivora (Petri) Buisman and

Received for publication 28 Mar. 1989. Oregon Agricultural Experiment Station Technical Paper no. 8894. We thank the Walker family for the establishment and maintenance of this orchard on their land. The cost of publishing this paper was defrayed in part by the payment of page charges. Under postal regulations, this paper therefore must be hereby marked advertisement solely to indicate this fact.

${ }^{1}$ Assistant Professor.

${ }^{2}$ Fu11 Professor

${ }^{3}$ Emeritus Professor.

${ }^{4}$ Extension Specialist.
P. megasperma Dreshler (Cummins et al., 1986).

A hybrid of Prunus avium x P. pseudocerasus, named Colt, was released by East Mailing Research Station, U.K. This rootstock is easy to propagate, Phytophthora-tolerant, precocious, and resistant to the bacterial canker-causing organism Pseudomonas syringae pv. morsprunorum (Mircetich and Matherton, 1981; Webster, 1984). Undesirable characteristics of Colt reported are poor drought tolerance, lack of winter hardiness, and lack of size control (Cummins et al., 1986; Oosten, 1979; Zahn, 1980).

New cherry orchards are often planted into

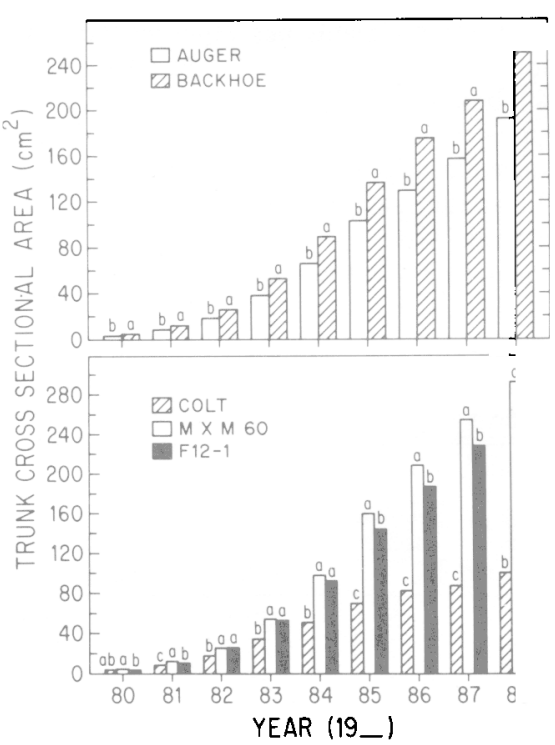

Fig. 1. Effect of preplant treatment and rootstock on trunk cross-sectional area of 'Napoleon' cherry trees from 1980 to 1988 . Means separation by Wailer-Duncan k-ratiot test, kratio $=100$. Means were obtained from 10 replicate trees. 